\title{
ATMOSPHERIC SOURCES, TRANSPORT AND DEPOSITION OF MERCURY IN MICHIGAN: TWO YEARS OF EVENT PRECIPITATION
}

\author{
M. HOYER, J. BURKE and G. KEELER 1
}

The University of Michigan, Air Quality Laboratory, Ann Arbor, MI 48109-2029 USA
\[ I_{\text {Author to whom correspondence should be addressed. }} \]

\begin{abstract}
To assess the sources, transport and deposition of atmospheric mercury ( $\mathrm{Hg}$ ) in Michigan, a multi-site network was implemented in which $\mathrm{Hg}$ concentrations in event precipitation and ambient samples (vapor and particulate phases) were determined. Results from the analysis of 2 years of event precipitation samples for $\mathrm{Hg}$ are reported here. The volume-weighted average $\mathrm{Hg}$ concentration in precipitation was $7.9,10.8$ and $10.2 \mathrm{ng} / \mathrm{L}$ for the Pellston, South Haven and Dexter sites, respectively. Yearly wet deposition of $\mathrm{Hg}$ for 1992-93 and 1993-94 was 5:8 and $5.5 \mu \mathrm{g} / \mathrm{m}^{2}$ at Pellston, 9.5 and $12.7 \mu \mathrm{g} / \mathrm{m}^{2}$ at South Haven and 8.7 and $9.1 \mu \mathrm{g} / \mathrm{m}^{2}$ at Dexter. A spatial gradient in both the $\mathrm{Hg}$ concentration and wet deposition was observed. Northern Michigan received almost half the deposition of $\mathrm{Hg}$ recorded at the southern Michigan sites. The concentration of $\mathrm{Hg}$ in precipitation exhibited a strong seasonal behavior with low values of 1.0 to $2.0 \mathrm{ng} / \mathrm{L}$ in winter and maximum values greater than $40 \mathrm{ng} / \mathrm{L}$ in summer. The spring, summer and autumn precipitation accounted for 89 to $91 \%$ of the total yearly Hg deposition. Mixed-layer back trajectories were calculated for each precipitation event to investigate the meteorological history and transport from potential $\mathrm{Hg}$ source regions. Elevated $\mathrm{Hg}$ concentrations were observed with air mass transport from the west, southwest, south, and southeast. At each of the sites precipitation events for which the $\mathrm{Hg}$ concentration was in the 90 th and 10 th percentile were-analyzed for trace elements by ICP-MS to investigate source impacts.
\end{abstract}

Keywords: Mercury, wet deposition, precipitation, trace elements, regional transport, trajectories

\section{Introduction}

Atmospheric tranśport and deposition of $\mathrm{Hg}$ has been recognized as an important link in the cycling of $\mathrm{Hg}$ in the environment (Lindqvist, 1985; Lindberg et al., 1991). Anthropogenic $\mathrm{Hg}$ sources in the U.S. and initial estimates of their annual emissions into the atmosphere have recently been reported (U.S. EPA, 1994). Since anthropogenic sources for $\mathrm{Hg}$ in the U.S. are numerous and generally not well characterized, an accurate emissions database which includes both anthropogenic and natural sources is not yet available. This fact coupled with an incomplete understanding of atmospheric processes for $\mathrm{Hg}$ limit the applicability of deterministic models in predicting the atmospheric behavior and deposition of $\mathrm{Hg}$ over short temporal and large spatial scales. To investigate the local and regional transport and deposition of $\mathrm{Hg}$, accurate, long-term measurements at multiple receptor locations should be obtained. To attempt to diagnose the source(s) and source regions culpable for the observed $\mathrm{Hg}$, concentrations of $\mathrm{Hg}$ in ambient air (both vapor and particle phases), and in event precipitation should be measured together with complementary chemical and meteorological parameters at multiple sites over time periods longer than one year.

Research conducted in Scandinavia (Brosset, 1987; Iverfeldt, 1991) identified a spatial gradient in the concentration of $\mathrm{Hg}$ in precipitation from northern to southern Sweden. Meteorological analysis indicated that the elevated levels of $\mathrm{Hg}$ observed in precipitation were associated with transport from the heavily industrialuzed region to the south and southeast of Sweden. In addition, $\mathrm{Hg}$ concentrations were correlated with concentrations of sulfate, $\mathrm{Cd}$ and $\mathrm{Pb}$ in precipitation, which suggested a connection

Water, Air, and Soil Pollution 80: 199-208, 1995.

(c) 1995 Kluwer Academic Publishers. Printed in the Netherlands. 
between the $\mathrm{Hg}$ found in precipitation and anthropogenic emissions upwind (Iverfeldt, 1991).

In the Great Lakes, indirect evidence suggesting a gradient in the deposition of $\mathrm{Hg}$ has been reported by Nater and Grigal (1992). A two fold increase of $\mathrm{Hg}$ content in surficial soils was observed from western Minnesota to northeastern Michigan. To investigate these findings and to determine the sources of the $\mathrm{Hg}$ deposition in the Great Lakes region, sampling for $\mathrm{Hg}$ and other chemical and meteorological parameters was conducted in Michigan from 1992 to 1994 . Measurements included event precipitation for the two years of the study, and vapor and particulate phase $\mathrm{Hg}$, as well as other atmospheric constituents on an every 6th day basis for the second year of the study. Data reported in this paper are limited to $\mathrm{Hg}$, major anions and trace elements. Sites were chosen to provide an adequate spatial resolution to characterize regional transport and to document spatial differences in the deposition of $\mathrm{Hg}$ in Michigan. In addition, source regions and source types culpable for the $\mathrm{Hg}$ measured were investigated using meteorological, elemental, and chemical data for precipitation events with elevated $\mathrm{Hg}$.

\section{Materials and Methods}

Event precipitation was collected for two years (March 1992 - March 1994) at three sites in Michigan: Pellston, South Haven and Dexter (Figure 1). The site near Pellston located at the University of Michigan Biological Station is also a National Atmospheric Deposition Program (NADP) site. The region around Pellston is mixed forest with areas of low intensity farming. The site in South Haven was located in a rural agricultural area $3 \mathrm{~km}$ east of Lake Michigan. The $\mathrm{Hg}$ monitoring at that site was collocated with atmospheric measurements as part of several studies investigating the loading of $\mathrm{Hg}$ and other toxic compounds to the Great Lakes. The Dexter site, located 25 miles northwest of

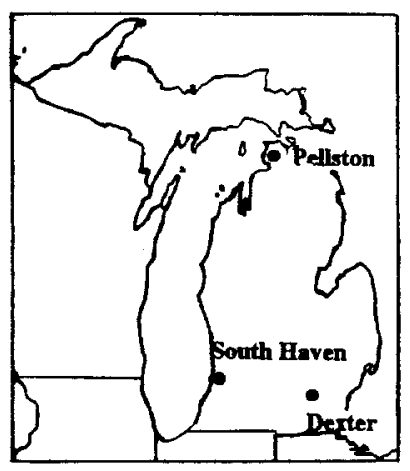

Fig. 1. Hg Measurement sites in Michigan Ann Arbor, MI is a U.S. EPA National Dry Deposition Network (NDDN) Site.

Precipitation samples were collected into a $10 \mathrm{~L}$ borosilicate glass (BSG) vessel using an MIC-B automatic collector (MIC Co., Richmond Hill, Ontario) with a Teflon-coated funnel. After each precipitation event, the sample was transferred from the $10 \mathrm{~L}$ collection vessel to a $1 \mathrm{~L}$ BSG bottle. With a funnel inlet area of $0.2 \mathrm{~m}^{2}$, precipitation events of $0.13 \mathrm{~cm}$ or greater provided sufficient volume for analysis. The $10 \mathrm{I}$ vessel was rinsed with ultra-pure water (containing $<0.2 \mathrm{ng} \mathrm{Hg} / \mathrm{L}$ ) after collection of each sample and was replaced biweekly. A field blank was performed biweekly to ensure that the system was contaminant-free. A Teflon-covered pad was installed on the undersir. 
of each funnel cover to shield the funnel from windblown dust and other particulate matter.

All sample bottles and glassware used in sample analysis were rigorously cleaned in an 11-day procedure involving an acetone rinse, detergent wash, multiple rinses with ultra-pure water, heating in $3 \mathrm{M} \mathrm{HCl}$ at $80^{\circ} \mathrm{C}$, and two separate soaking periods in $0.6 \mathrm{M}$ $\mathrm{HNO}_{3}$ followed by extensive rinsing in ultra-pure water in a Class 100 clean room (Rossmann and Barres, 1991). Ultra-clean techniques were used in all phases of sample collection and analysis. Samples were shipped by overnight mail to the University of Michigan Air Quality Lab (UMAQL) in Ann Arbor, MI. A Belfort rain gauge located at each site was used to determine the volume and time of each precipitation event.

When samples were received at UMAQL a subsample was poured off and acidified for analysis of trace metals by inductively coupled plasma mass spectrometry (ICP-MS). A separate subsample was poured off for analysis of $\mathrm{pH}$ and major ions by ion chromatography. The remaining sample was oxidized with bromine monochloride to a $1 \%$ solution for analysis of total $\mathrm{Hg}$ by cold vapor atomic fluorescence spectrometry (Fitzgerald and Gill, 1979). At the start of the study, the detection limit for total $\mathrm{Hg}$, defined as $3 \sigma$ of the reagent blank, was $0.095 \mathrm{ng} / 100 \mathrm{~mL}$ sample. The detection limit was reduced to the current level of $0.015 \mathrm{ng} / 100 \mathrm{~mL}$ sample with the use of more purified $\mathrm{HCl}$ and bromine salts. All samples were initially analyzed in duplicate. After the first 6 months through the end of the study $50 \%$ of the samples were analyzed in duplicate. The average analytical precision over the duration of this study was $6 \%$.

Procedures required to implement and operate a multi-site network for collection and analysis of event precipitation for $\mathrm{Hg}$ are described in Hoyer and Keeler (1994a). The manuscript details experiments including collocated manual and automatic collectors, interlaboratory comparisons and investigation of the stability of $\mathrm{Hg}$ in precipitation. Results from the first year of network operation are reported elsewhere (Hoyer et al., 1993).

Three-day backward mixed-Iayer trajectories were calculated for each day on which precipitation was collected. Air mass trajectories define the most probable path of an air mass before arriving at a specified receptor site. Trajectories were calculated from upper air data collected at National Weather Service monitoring stations (Heffter, 1980).

\section{Results and Discussion}

\subsection{Hg CONCENTRATION IN PRECIPITATION}

During the two years of event precipitation collection, a total of 153 samples were collected at Pellston, 188 at South Haven and 181 at Dexter- The two year mean $\mathrm{Hg}$ concentration in precipitation was $7.9 \mathrm{ng} / \mathrm{L}$ at Pellston, $10.8 \mathrm{ng} / \mathrm{L}$ at South Haven and $10.2 \mathrm{ng} / \mathrm{L}$ at Dexter (Table I).

Variability in the precipitation $\mathrm{Hg}$ concentration between the sites was clearly evident. The maximum concentration observed at the northern Michigan site in Pellston was approximately $20 \%$ tower than the maximum at the southwestern Michigan site in South Haven and the southeastern Michigan site in Dexter. Precipitation events with elevated $\mathrm{Hg}$ were also less frequent at the Pellston site than at the two southern Michigan sites. The standard deviation of the $\mathrm{Hg}$ concentration in precipitation at South Haven was 
higher than at the other two sites largely due to the elevated Hg concentrations in several summer samples collected at the site.

TABLE I

Total Hg in precipitation in Michigan (ng/L), Mar 1992-Mar 1994

\begin{tabular}{|lccccc|}
\hline SITE & $\mathrm{n}$ & $\begin{array}{c}\text { Volume-Weighted } \\
\text { Average }\end{array}$ & Std Dev & Range & $\begin{array}{c}\text { 90th } \\
\text { Percentile }\end{array}$ \\
\hline Pellston, MI & 153 & 7.9 & 7.4 & $1.4-47.6$ & 16.6 \\
South Haven, MI & 188 & 10.8 & 11.2 & $1.2-59.5$ & 25.7 \\
Dexter, MI & 181 & 10.2 & 9.8 & $1.8-55.2$ & 19.6 \\
\hline
\end{tabular}

The concentration of $\mathrm{Hg}$ in precipitation varied seasonally at each of the sites (Figure 2). Average $\mathrm{Hg}$ concentrations for the spring and summer were a factor of two greater than those in winter, except at the Dexter site where two high concentration events occurred in winter 1994 which elevated the mean. Year-to-year differences in the seasonal average $\mathrm{Hg}$ concentration in precipitation are evident (Figure 2). The average $\mathrm{Hg}$ concentration was $14 \%$ and $25 \%$ lower in the summer of 1992 at South Haven and Dexter, respectively, than in summer of 1993. This may have resulted from lower than average ambient temperatures during the summer 1992, but more years of sampling would be required to adequately characterize seasonal differences on a year-to-year basis. The average $\mathrm{Hg}$ concentration in precipitation in winter 1994 at Dexter was higher than that in winter 1993. This was uncharacteristic when compared to measurements at the other sites. This elevated average was due to one event in Feb 1994 and two events in Mar 1994 for which the concentration of $\mathrm{Hg}$ was greater than $20 \mathrm{ng} / \mathrm{L}$. These storms deposited precipitation with slow transport from the east (Detroit metropolitan area).

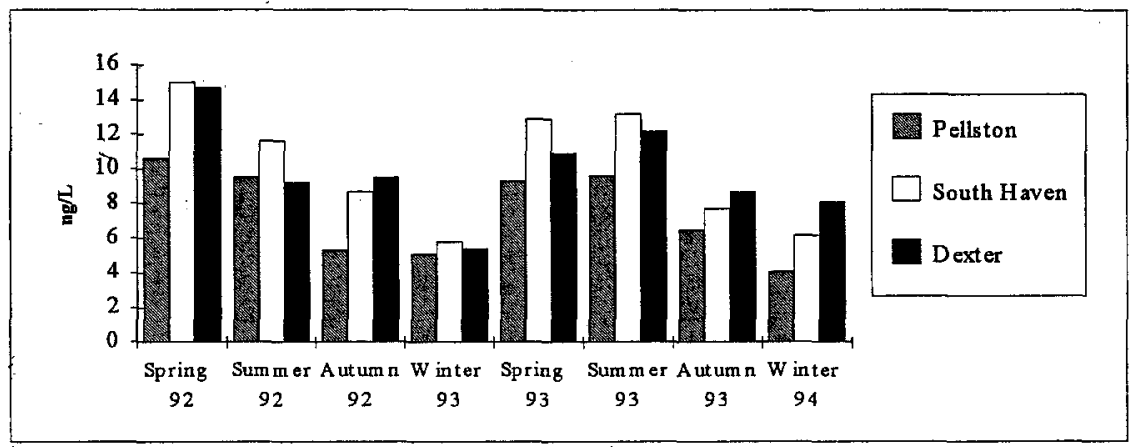

Fig. 2. Volume-weighted average $\mathrm{Hg}$ concentration in precipitation 1992 - 1994.

Many factors, both chemical and physical, may influence the seasonal variation in the concentration of $\mathrm{Hg}$ in precipitation. Those factors include precipitation type, source influences, atmospheric oxidant concentration (Munthe et al., 1991), in-cloud processes (Borys et al., 1988), meteorology and chemical/physical aspects of the aerosol population. Borys et al. (1988) reported that the concentration of constituents in frozen precipitation may be strongly influenced by in-cloud growth processes (accretion and vapor deposition). Several in-cloud processes are potentially important factors which 
may control the concentration of $\mathrm{Hg}$ in cloud droplets and subsequently in precipitation. These include in-cloud temperature, turbulence, aerosol size distribution, and chemical properties of the atmospheric aerosol incorporated into the cloud system. Chemical parameters of importance include oxidant concentrations and the particulate and vapor species in the air which feeds the precipitating cloud system (Munthe et al., 1991).

\section{$3.2 \mathrm{Hg}$ WET DEPOSITION}

During the first year of measurement, the total $\mathrm{Hg}$ wet deposition observed at South Haven was $9.45 \mu \mathrm{g} / \mathrm{m}^{2}$ while at Pellston and Dexter the wet deposition was 5.79 and $8.66 \mu \mathrm{g} / \mathrm{m}^{2}$, respectively (Table II). The wet deposition of $\mathrm{Hg}$ was substantially higher in the second year of sampling at South Haven, but nearly identical for both years at Pellston and Dexter. The increase in deposition measured at South Haven resulted from an increased precipitation rate. Event $\mathrm{Hg}$ wet deposition measurements in Underhill, VT made from Dec 1992-'93 also demonstrate the importance of precipitation amount on yearly loading (Burke et al., this volume). During this one year period, the average volume-weighted $\mathrm{Hg}$ concentration at the site in Vermont $(8.3 \mathrm{ng} / \mathrm{L})$ was similar to that observed at Pellston $(7.9 \mathrm{ng} / \mathrm{L})$. However, $\mathrm{Hg}$ deposition observed at the Vermont site was $9.26 \mu \mathrm{g} / \mathrm{m}^{2}$, substantially higher than that measured at Pellston. The measured values at the Pellston site are also lower than values estimated from measurements in northern Wisconsin at similar latitudes (Fitzgerald et al., 1991), and from measurements of weekly precipitation collected in Ontario (Mierle, 1990). These differences may be due to sampling frequency, precipitation amount and/or differences in source impacts.

A spatial gradient in the deposition of $\mathrm{Hg}$ was observed in Michigan in this study. South Haven received 1.6 and 2.3 times more $\mathrm{Hg}$ deposition than Pellston in the two respective years of sampling. While the spatial differences in $\mathrm{Hg}$ wet deposition are clearly a function of the different amounts of precipitation received, the difference in $\mathrm{Hg}$ concentration at the sites also contributes substantially to the regional gradient in wet deposition of $\mathrm{Hg}$. 'In 1992-'93 South Haven received 1.2 times more precipitation than Pellston and 1.6 times more Hg was deposited in South Haven. In 1993-'94 South Haven received 1.6 times more precipitation than Pellston, but 2.3 times the $\mathrm{Hg}$ wet deposition. The yearly precipitation totals in 1992-'94 were within $10 \%$ of the 30-year climatological average for these regions in Michigan (NOAA, 1992). However, the precipitation received at South Haven in 1993-'94 was $24 \%$ higher than the 30-year average.

Seasonal variation in the wet deposition of $\mathrm{Hg}$ was also observed in both years of measurement with summer storms delivering 3 to 5 times more $\mathrm{Hg}$ than winter storms (Figure 3). Note that while the volume-weighted average concentration of $\mathrm{Hg}$ in precipitation collected at Dexter was elevated in winter 1994 compared to winter 1993, the deposition for this season was similar in the two years of study. $\mathrm{Hg}$ wet deposition occurring during winter of $1992-193$ accounted for only $6 \%$ of the total $\mathrm{Hg}$ deposition at Pellston, 7\% at South Haven and $15 \%$ at Dexter. Wintertime $\mathrm{Hg}$ wet deposition in 1993'94 contributed $7 \%$ of the yearly total at both Pellston and Dexter and $8 \%$ at South Haven. The largest portion of the annual $\mathrm{Hg}$ wet deposition occurred in the spring and summer months at each of the sites with $34 \%$ of the total being deposited during those seasons. Hg wet deposition during the autumn periods averaged $22 \%$ of the total annual wet deposition at the three sites. 
Table II

Deposition of $\mathrm{Hg}$ in precipitation $\left(\mu \mathrm{g} / \mathrm{m}^{2}\right)$, Mar 1992-Mar 1994

\begin{tabular}{|lcccccc|}
\hline SITE & $\begin{array}{c}\text { Event } \\
\text { Avg }\end{array}$ & $\begin{array}{c}\text { Event } \\
\text { Max }\end{array}$ & $\begin{array}{c}1992-' 93 \\
\text { Deposition }\end{array}$ & $\begin{array}{c}1993-' 94 \\
\text { Deposition }\end{array}$ & $\begin{array}{c}1992-' 93 \\
\text { Precip Amnt, } \\
\text { cm }\end{array}$ & $\begin{array}{c}1993-' 94 \\
\text { cm Amnt, }\end{array}$ \\
\hline Pellston, MI & 0.07 & 0.51 & 5.79 & 5.54 & 73 & 71 \\
South Haven, MI & 0.12 & 0.85 & 9.45 & 12.67 & 89 & 116 \\
Dexter, MI & 0.10 & 0.98 & 8.66 & 9.11 & 87 & 88 \\
\hline
\end{tabular}

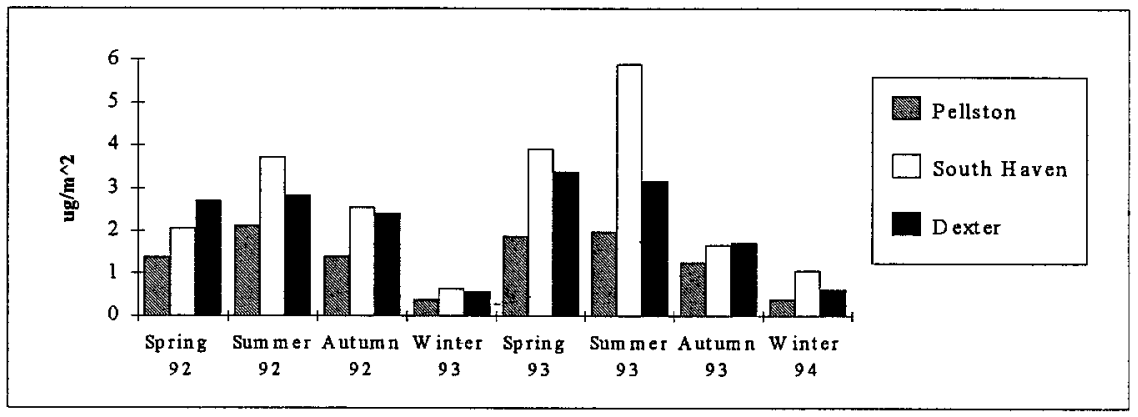

Fig. 3. Mercury wet deposition by season in Michigan 1992 - 1994.

Individual precipitation events resulted in $\mathrm{Hg}$ wet deposition from $0.002 \mu \mathrm{g} / \mathrm{m}^{2}$ to a high of $0.984 \mu \mathrm{g} / \mathrm{m}^{2}$ measured at Dexter in 1992-'93 which represented $10.8 \%$ of the total annual deposition. Elevated $\mathrm{Hg}$ deposition events (90th percentile by site) were generally the result of large volume precipitation events with average or above average $\mathrm{Hg}$ concentration. At all sites precipitation events in the 90 th percentile for $\mathrm{Hg}$ concentration accounted for 18 to $22 \%$ of the cumulative $\mathrm{Hg}$ wet deposition for the twoyear period while the 10th percentile events accounted for only 3 to $6 \%$ of the $\mathrm{Hg}$ wet deposition.

For this study, precipitation events which accumulated less than $0.13 \mathrm{~cm}$ did not produce sufficient volume for a complete chemical and elemental analysis. The contribution of these events was estimated using the average concentration in events which accumulated 0.13 to $0.25 \mathrm{~cm}$ for the month during which the low-volume event occurred. This estimation procedure was used because of the seasonal variation in $\mathrm{Hg}$ concentration and the relationship between precipitation and concentration amount (lower volume events have a higher $\mathrm{Hg}$ concentration, Hoyer and Keeler, 1994b). The estimated deposition from these events was not included in Table II. These small events were estimated to have contributed $4 \%$ of the two year total at Pellston, $2 \%$ at South Haven and $3 \%$ at Dexter. These data indicate that collection of events less than $0.13 \mathrm{~cm}$ is not important in accurately assessing wet deposition when event samples are collected throughout the year. 


\subsection{TRANSPORT AND SOURCE CHARACTERISTICS}

Air mass trajectories are a useful tool in the analysis of air and precipitation chemistry measurements (Pierson et al., 1986; Keeler et al., 1990; Moody and Galloway, 1988). However, interpretation of trajectory measurements should not be undertaken without full knowledge of the associated uncertainties and the limitations inherent in the meteorological measurements on which they are based (Kahl, 1993). An initial investigation of the meteorological associations and potential sources influencing the $\mathrm{Hg}$ concentrations measured in event precipitation samples was performed. Mixed-layer back trajectories were plotted for each event and a suite of trace elements in samples with elevated $\mathrm{Hg}$ were analyzed. The relative abundance and combination of the elements quantified were used to characterize potential sources. Previous work has demonstrated that trace element components of a transported aerosol mass and metal ratios reveal specific source influences (Rahn and Lowenthal, 1984; Keeler and Samson, 1989).

The highest $\mathrm{Hg}$ concentrations (90th percentile) were typically associated with air mass transport from the west, southwest, south and southeast of the sites in Michigan (Figures 4a-b). Although less frequently, events elevated in $\mathrm{Hg}$ were also observed with transport from the north and east to each of the sites. Upwind stagnation was evident for a few of the 90th percentile events which has been previously shown to result in elevated anion levels in precipitation (Pierson 'et al., 1989; Moody and Samson, 1989). Trajectories plotted for 10 th percentile events indicated that transport from the north, northwest, and east (frequently accompanied by rapid advection) often resulted in low $\mathrm{Hg}$ concentration in precipitation.

Trace element concentrations in precipitation events with high $\mathrm{Hg}$ at the South Haven site were investigated for potential source markers. On 11 May 94 and 24 May 94 transport to South Haven was from the northwest and these events had elevated concentrations of $\mathrm{Hg}, \mathrm{V}, \mathrm{Pb}, \mathrm{Fe}, \mathrm{Zn}, \mathrm{Mn}, \mathrm{Cu}, \mathrm{NO}_{3}{ }^{-}$and $\mathrm{SO}_{4}{ }^{2-}$ (elevated in comparison to concentrations in other samples in the 90 th and 10th percentile for $\mathrm{Hg}$ ). The sample collected on 24 May 94 also contained elevated levels of As and Se and especially elevated $\mathrm{NO}_{3}{ }^{-}$and $\mathrm{SO}_{4}{ }^{2-}$ concentrations. These elemental concentrations indicate potential contributions from metals processing, iron and steel manufacturing, and oil and coal combustion.

During the summer months, with prevailing winds from the southwest, the South Haven site received storms with feed air from one of the largest $\mathrm{Hg}$ emission source areas in the region. According to the draft EPA Emissions Inventory (U.S. EPA, 1994), Cook County and the three counties surrounding it at the southern tip of Lake Michigan emit more than 5.0 tons of $\mathrm{Hg}$ /year. The number and variety of $\mathrm{Hg}$ and other trace element source types are diverse in this region so that characterization of $\mathrm{Hg}$ sources using measurements at receptor sites requires analysis of the intersection of a large number of precipitation events representing different meteorological conditions. Events elevated in $\mathrm{Hg}$ concentration arriving at the South Haven site from the southwest all had elevated concentrations of $\mathrm{Pb}, \mathrm{Fe}, \mathrm{Zn}, \mathrm{Mn}, \mathrm{As}, \mathrm{Cd}, \mathrm{Se}, \mathrm{V}, \mathrm{NO}_{3}$ and $\mathrm{SO}_{4}{ }^{2-}$ reflecting a variety of possible source influences including coal combustion, oil combustion, metals processing (ferrous and non-ferrous) and incineration. 


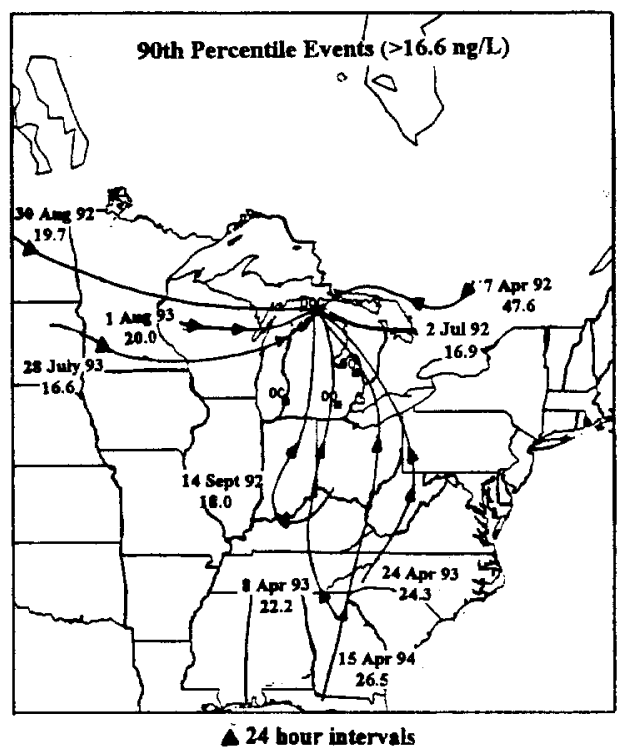

Fig. 4a. Pellston Mired-Layer Trajectories

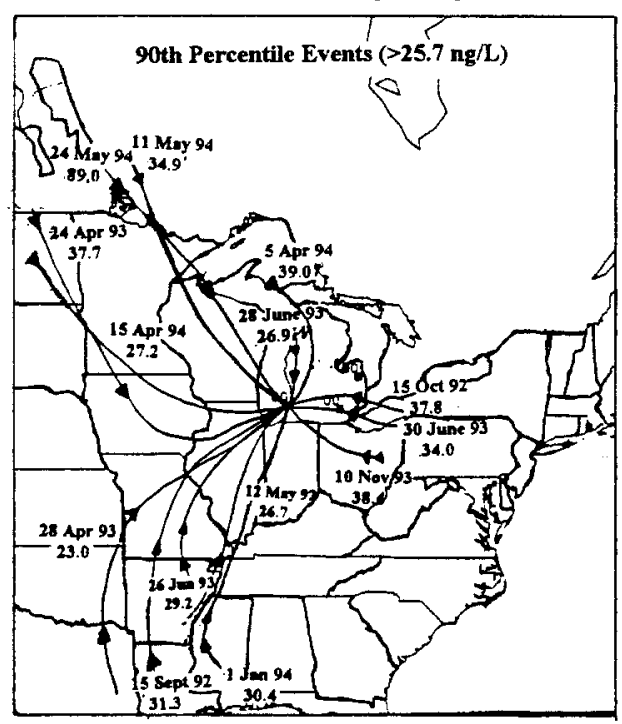

Fig. 4b. South Haven Mired-Layer Trajectories

Each trajectory is labeled with the date of precipitation and concentration of $\mathrm{Hg}$ in $\mathrm{ng} / \mathrm{l}$. 
In general, when $\mathrm{Hg}$ was elevated other trace metals in the sample were also elevated indicating common source(s) and/or source regions. Also, when a sample was low in $\mathrm{Hg}$ concentration it was generally accompanied by low elemental and anion levels. However, for samples in the 10th percentile for $\mathrm{Hg}$ concentration, there were two events at Pellston, one at South Haven and one at Dexter which had an elevated level of one or more other elements. A snow storm at Pellston on $19 \mathrm{Dec} 1993$ with $\mathrm{Hg}$ concentration of $2.0 \mathrm{ng} / \mathrm{L}$ was highly elevated in $\mathrm{Ni}, \mathrm{Pb}, \mathrm{Fe}, \mathrm{Zn}, \mathrm{As}, \mathrm{Cd}, \mathrm{Se}, \mathrm{Cu}$ and $\mathrm{Cr}$ and slightly elevated in $\mathrm{Mn}$ and V. The trajectory for this event indicates air mass transport from west-southwest of the site. On a second occasion at Pellston (10 Sept 1993) a precipitation sample had $2.6 \mathrm{ng} / \mathrm{L}$ of $\mathrm{Hg}$ but contained highly elevated $\mathrm{Pb}$ and $\mathrm{Cd}$. Air mass transport for this event was very rapid and directly out of the northwest traveling over potential metals sources in the Upper Peninsula of Michigan. On 19 Feb 1994 a snow sample at Pellston contained $2.8 \mathrm{ng} / \mathrm{L} \mathrm{Hg}$ and elevated $\mathrm{Mn}, \mathrm{V}$ and $\mathrm{Cr}$ indicating potential input from oil combustion sources and non-ferrous metal manufacture.

At South Haven only one of the 10th percentile events contained elevated levels of trace metals other than $\mathrm{Hg}$. Frozen precipitation that fell on $25 \mathrm{Feb} 1994$ contained 3.1 $\mathrm{ng} / \mathrm{L} \mathrm{Hg}$ but had elevated $\mathrm{Cu}$ and a moderate level of $\mathrm{Pb}, \mathrm{Zn}$ and $\mathrm{Mn}$. Trajectories plotted for events in the 10th percentile for $\mathrm{Hg}$-concentration indicated that a source region contributing to elevated $\mathrm{Hg}$ may, on occasion, contribute to very low levels of $\mathrm{Hg}$ in precipitation. Clearly, factors other than air mass origin were affecting the constituent load in precipitation. Precipitation type, storm type (convective vs. frontal), wind speed, other boundary layer parameters, and the $\mathrm{Hg}$ chemistry itself could have affected the $\mathrm{Hg}$ concentration in precipitation from storms which arrive from known source regions.

\section{Conclusions}

Analysis of two years of event precipitation samples at three sites in Michigan has resulted in several findings to date. A gradient in both the $\mathrm{Hg}$ concentration and wet $\mathrm{Hg}$ deposition in Michigan was observed with the northern Michigan site receiving less $\mathrm{Hg}$ than the southern Michigan sites. The Hg concentration in event precipitation samples varied by season with $\mathrm{Hg}$ concentrations two times greater during spring and summer months than during winter. The data suggest that the sources of $\mathrm{Hg}$ measured at the sites are of regional origin (within and outside of Michigan) and that proximity to known anthropogenic sources significantly influence the concentration and wet deposition of $\mathrm{Hg}$ in the Great Lakes basin. Assessment of event deposition over a-two-year period has enabled an accurate measurement of total $\mathrm{Hg}$ loading to the lower peninsula of Michigan in the Great Lakes basin. This study provides the first spatially resolved event $\mathrm{Hg}$ wet deposition data in the region. These results can be used to improve model estimates of the wet $\mathrm{Hg}$ flux in this region.

Several studies have now documented a seasonal trend in the $\mathrm{Hg}$ concentration in precipitation and in the wet deposition of $\mathrm{Hg}$ (Burke et al., this volume; Glass et al., 1986). This observation is possibly due to combined effects of chemistry and physical processes (e.g. ozone and other in-cloud oxidant concentration, physical factors in-cloud involved in the growth of rain droplets and ice crystals). To elucidate the dominant factors controlling the seasonal variation of $\mathrm{Hg}$ in precipitation, further investigations of the concentrations and reaction rates for $\mathrm{Hg}$ and other ions and constituents in 
precipitation are needed as well as better understanding of $\mathrm{Hg}$-containing aerosols, their size distributions, concentrations, and their role in precipitation formation.

Mixed-layer trajectories indicate that the dominant sources of $\mathrm{Hg}$ to the Michigan sampling sites are located to the west, southwest, south and southeast. Investigating the cross-section of several events that contained elevated $\mathrm{Hg}$ concentration provides the ability to separate meteorological influences from source effects on precipitation chemistry. Specific source types can also be identified with the use of tracer compounds measured in the precipitation.

In order to investigate sources utilizing the receptor-based approach employed in this study, short duration (event) precipitation samples need to be collected for at least one year in order to assess sample to sample variability, inter-site differences; seasonal variation and meteorological factors which can drastically alter precipitation chemistry.

\section{Acknowledgments}

This work was supported by the Michigan Great Lakes Protection Fund and the University of Michigan. The success of the project was due to the hard work of our three dedicated site operators: Robert Vande Kopple (Pellston), Mary Barden (South Haven) and Katherine Beverstock (Dexter). Several individuals at the University of Michigan Air Quality Laboratory contributed substantially to sample analysis. In particular we thank Jennifer Falk, Lisa Cleckner, Elizabeth Esseks and Am Krueger. We thank J. Timothy Dvonch and Tamar Krantz for anion and pH analysis and Jim Barres for help with ICP-MS analysis. Additional thanks is given to Kristie Mukherjee who digitized the Belfort rain gauge charts for each precipitation event. The authors also thank the reviewers for their comments and suggestions.

\section{References}

Borys, R.D, Hindman, E.E. and Demott, P.J.: 1988, J Atmos Chem. 7, 213.

Brosset, C.: 1987, Water, Air and Soil Pollut. 34, 145.

Burke, J., Hoyer, M., Keeler, G. and Scherbatskoy, T.: this volume.

Fitzgerald, W.F., Mason, R.P. and Vandal, G.M.: 1991, Water, Air and Soil Pollut. 56,745.

Fitzgerald, W.F. and Gill, G.A.: 1979, Anal. Chem. 51, 1714.

Glass, G.E., Leonard, E.N., Chan, W.H. and Orr, D.B.: 1986, J. Great Lakes Res. 12, 37.

Heffter, J.L.: 1980, NOAA-Technical Memo; ERL ARL-81; Rockville, MD. p 17.

Hoyer, M., Burke, J., Mukherjee, K., Cleckner, L. and Keeler, J.: 1993, 9th Int. Conf. on Heavy Metals in the Environment Toronto, Canada September. p.332.

Hoyer, M.E. and Keeler, G.J.: 1994a, submitted to Environ. Sci. \& Technol.

Hoyer, M.E. and Keeler, G.J.: 1994b, submitted to Atmos. Environ.

lverfeldt, A: 1991, Water, Air and Soil Pollut. 56, 251.

Kahl, J.: 1993, Atmos. Env. 27A, 3037.

Keeler, G.J. and Samson, P.J.: 1989, Environ. Sci.\& Technol. 23, 1358.

Keeler, G., Spengler, J., Koutrakis, P., Allen.G., Raizenne, M. and Stern, B.: 1990, Atmos. Environ. 24A, 2935.

Lindberg, S., Turner, R., Meyers, T., Taylor, Jr. G., and Schroeder, W.: 1991, Water, Air and Soil Pollut. 56, 577.

Lindqvist, O.: 1985, Tellus 37B, 136.

Mierle, G.: 1990, Environ. Tox. and Chem. 9, 843.

Moody, J.L. and Samson, P.J.: 1989, Atmos. Environ. 23, 2117.

Moody, J.L. and Galloway, J.N.: 1988, Tellus 40B, 463.

Munthe, J.: 1991, Atmos. Environ. 26A:1461.

Nater, E.A and Grigal, D.F.: 1992, Nature 358, 139.

NOAA: 1992, Climatological data annual summary for Michigan 107, 13. ISSN 0145-045X.

Pierson, W., Brachaczek, W., Gorse, R., Jr, Japar, S., Norbeck, J. and Keeler, G.: 1986, Environ. Sci Technol. 21, 679.

Pierson, W., Brachaczek, W., Gorse, R., Jr, Japar, S., Norbeck, J. and Keeler, G.: , 1989, Atmos. Environ. $23,431$.

Rahn, K.A. and Lowenthal, D.H.: 1984, Science 223, 132.

Rossmann, R. and Bartes, J.: 1991, J. Great Lakes Res. 14, 188.

U.S. EPA. Emission Inventory Mercury Study Report to Congress: 1994. 